AMERICAN UNIVERSITY WORKING PAPER SERIES

\title{
HOW DO COUNTRIES RESPOND TO ANTIDUMPING FILINGS? DISPUTE SETTLEMENT AND RETALIATORY ANTIDUMPING
}

\author{
Robert M. Feinberg \\ Kara M. Reynolds \\ Working Paper 2017-08 \\ http://www.american.edu/cas/economics/research/upload/2017-08.pdf
}

JEL No.: F13

\begin{abstract}
AMERICAN UNIVERSITY
4400 Massachusetts Ave., N.W.,
\end{abstract}

Washington, D.C. 20016-8029

\begin{abstract}
Empirical studies have found that countries may respond strategically to the antidumping petitions filed against their exporters through their own retaliatory actions. Although most previous studies have focused on retaliatory antidumping filings, in this paper we explore another potential avenue for strategic response - filing a complaint under the World Trade Organization's (WTO) Dispute Settlement Understanding. Using a panel of global antidumping filings between 1995 and 2011, we analyze under what conditions countries will choose to retaliate through either an antidumping petition or a WTO dispute, and to what degree these two strategies are complementary or act as substitutes. We find statistical evidence that countries are more likely to file a WTO dispute when they have also filed a retaliatory antidumping petition, suggesting that these two strategies may be complementary.
\end{abstract}




\title{
How Do Countries Respond to Antidumping Filings? Dispute Settlement and Retaliatory Antidumping*
}

\author{
Robert M. Feinberg and Kara M. Reynolds \\ American University
}

March 2017

\begin{abstract}
Empirical studies have found that countries may respond strategically to the antidumping petitions filed against their exporters through their own retaliatory actions. Although most previous studies have focused on retaliatory antidumping filings, in this paper we explore another potential avenue for strategic response-filing a complaint under the World Trade Organization's (WTO) Dispute Settlement Understanding. Using a panel of global antidumping filings between 1995 and 2011, we analyze under what conditions countries will choose to retaliate through either an antidumping petition or a WTO dispute, and to what degree these two strategies are complementary or act as substitutes. We find statistical evidence that countries are more likely to file a WTO dispute when they have also filed a retaliatory antidumping petition, suggesting that these two strategies may be complementary.
\end{abstract}

\footnotetext{
* American University, 4400 Massachusetts Avenue, NW, Washington, DC 20016. Feinberg: e-mail: feinber@american.edu; Telephone: (202) 885-3788. Reynolds: e-mail: reynolds@american.edu; Telephone: (202) 885-3768.

Earlier versions of this paper were presented at the 2016 Southern Economic Association meetings, the 2017 Eastern Economic Association meetings, and at a WTO seminar. We thank Michael Ferrantino, Ben Liebman, William Miles, Roberta Piermartini, and Maurizio Zanardi for helpful comments.
} 


\section{Introduction}

A growing literature has explored motivations for antidumping (AD) usage (and its spread to a much wider group of user countries) since the mid-1990s (e.g., Miranda et al. (1998), Zanardi (2004)). One factor noted has been the strategic use of antidumping in retaliation for earlier cases (especially for new/developing-country users). However most of this work has ignored the other mechanisms that targets of antidumping petitions have for response or retaliation.

From another perspective, both economic and legal scholars have examined the role of the WTO's Dispute Settlement Understanding (DSU) procedures, providing evidence on trends in this usage by both developed and developing countries and attempting to econometrically explain determinants of these patterns. However, little of this work has discussed the inter-relationships between AD and DSU mechanisms.

In this paper, we examine the quite large number of post-1995 AD filings, and ask several questions: what determines a response by target (exporting) countries? If a response, is this via the DSU or by filing a (retaliatory) AD case? What other determinants of DSU filings are important?

\section{Motivation/Theory}

Bown (2002) considers motivations for filing AD cases in the context of a model in which targeted (exporting) countries have the option of requesting a panel under the DSU. While the framework accounts for the determinants of the latter decision, what is 
not explicitly modeled is the potential response in the form of a retaliatory AD filing (against the same or different industry in the country of the original AD petitioner). Busch, Reinhard, Shaffer (2008) find that developing countries with little "legal capacity" are less likely to challenge AD (and other trade measures) at the WTO; however, what they do not pursue is the question of whether they respond in other ways, such as retaliatory AD.

Much research has considered whether AD cases may be filed in part as retaliation for other such actions. Prusa (2001) briefly discusses the strategic issues involved in a government's decision to adopt an AD policy (we recognize that firms, not governments, initiate AD cases but - especially in the developing world - the distinction between the two may not be meaningful), while Prusa and Skeath (2002) present some evidence consistent with strategic motivations in AD petitions.

Blonigen and Bown (2003) develop a formal trigger-price model allowing for threats of $\mathrm{AD}$ actions against a country to limit that country's own $\mathrm{AD}$ activity, and produce supportive evidence for the United States. However, Francois and Niels (2004) suggest that new users may be initiating $\mathrm{AD}$ actions to retaliate against countries taking AD action against their exports (focusing on data for Mexico). Feinberg and Reynolds (2006) apply probit analysis to a large database on reported filings, and find strong evidence that retaliation was a significant motive in explaining the rise of AD filings over the first decade of the WTO, particularly for new user countries. 
More recently, the role of the WTO's dispute settlement understanding (DSU) mechanism has attracted attention of economists. ${ }^{1}$ Bown (2005a), examining DSU cases between 1995 and 2000, analyzed the decision to participate (of all countries affected by a particular trade practice in dispute); while the amount of exports potentially at stake was a determinant, there was also the suggestion of an "institutional bias" involving legal capacity which adversely impacted developing economies. Bown (2005b) expands on this, allowing the DSU response to US antidumping measures (in the 1992-2003 period) to depend not only on the size of the targeted country's affected exports, but also on that country's share of US global exports, and on their imports as a share of the protected US industry's production. The negative coefficient on the latter term is taken as an indicator of substitutability between DSU and retaliatory AD (though he doesn't examine whether retaliatory $\mathrm{AD}$ actually occurred). ${ }^{2}$

Bown and Reynolds (2015) discusses a set of stylized facts regarding the trade that countries fight about under WTO dispute settlement, including the levels of and changes to the trade values, market shares, volumes, prices, and scope of products that eventually become subject to WTO litigation. Perhaps of most interest to our study is their finding that there is a striking amount of heterogeneity in the trade flows associated with WTO disputes. For example, while the average complainant filing a dispute at the WTO suffered a 21 percent decrease in exports associated with the alleged violation, over 25 percent of the complainants in their sample experienced an increase in exports to

\footnotetext{
${ }^{1}$ Other work on determination of who files DSU cases, but not relating to AD retaliation, includes that of Guzman and Simmons (2005), Horn et al. (2005), Davis and Bermeo (2009), and Johns and Pelc (2013).

${ }^{2}$ Hartigan and Vandenbussche (2013), in a theoretical and legal analysis, discuss how retaliatory AD may substitute for and - in some cases - be preferable to DSU litigation, especially for developing countries.
} 
the respondent country following the alleged violation. Bown and Reynolds (2017) found evidence that countries may use the WTO disputes settlement system to address terms of trade externalities associated with trade policy shifts such as new antidumping orders.

In this paper, we explore the implications of the added option that the DSU brings to targets of AD measures. Examining all antidumping petitions filed between 1995 and 2011, we attempt to explain a target country's choice to respond, and if so whether to retaliate via its own $\mathrm{AD}$ petition or to go through the $\mathrm{DSU} .{ }^{3}$ We are particularly interested whether retaliatory AD petitions may be a substitute or a complement to challenging the $\mathrm{AD}$ action in the DSU system. Of course, there may be other ways that countries (and/or the targeted firms) can respond (health and safety regulatory restrictions, escape clause/safeguard cases, or simply raising applied tariffs if below bound levels), and we do not claim to be capturing all of these in our work. ${ }^{4}$

To illustrate, consider a simple situation in which the foreign country files an antidumping action against the domestic country. Following this action, the domestic country has several potential responses: (1) do nothing; (2) file a retaliatory antidumping action against the foreign country; (3) file a complaint with the WTO's dispute settlement

\footnotetext{
${ }^{3}$ At the time we started this research we observed antidumping filings through 2014 , and so limit our sample to the period from 1995 to 2011 to allow up to three years for a country to file a retaliatory dispute at the WTO.

${ }^{4}$ Bown (2014) examines, for Turkey, recent patterns in usage of various forms of trade protection. Limao and Tovar (2011) examine the trade policy choice between tariffs and non-tariff barriers, also using Turkish data.
} 
body; or (4) file both a retaliatory antidumping action and complaint at the WTO. ${ }^{5}$ Clearly, the country will only pursue those forms of retaliation in which the marginal benefits exceed the marginal costs.

The marginal cost of both forms of retaliation include legal costs, which may be significant and vary across countries. To pursue a case at the WTO, for example, Bown and Reynolds (2015) report that the minimum private sector legal fees of litigating a dispute at the WTO through the panel stage likely ranges from $\$ 250,000$ to $\$ 750,000$, depending on the law firm involved. However, there is likely some heterogeneity across countries in the cost of pursuing disputes, depending on both the degree of legal capacity and the level of development of the domestic country. ${ }^{6}$ For those countries with an active antidumping case load, the costs of pursuing a retaliatory antidumping case may be relatively modest in comparison as most petitions would be processed by government bureaucrats in the domestic country.

Both forms of retaliatory actions may be geared toward pressuring the foreign country to remove the antidumping measures. In the case of a retaliatory antidumping action, the domestic country may hope to force the foreign country to remove its antidumping measure in exchange for the domestic country lifting its retaliatory case. Although the results could be fairly quick (under US antidumping law, for example, the

\footnotetext{
${ }^{5}$ We acknowledge that countries with little to no experience (and institutional capacity) in using antidumping laws may be less likely to retaliate by filing an antidumping action. In the empirical work we control for this possibility by including a variable that measures the targeted countries historical antidumping usage.

${ }^{6}$ The Advisory Centre on WTO Law subsidizes the legal costs of developing country members who would like to pursue a dispute at the WTO, which could significantly reduce the costs.
} 
government can review antidumping margins in an annual review process), most countries review antidumping duties for potential elimination only every five years in sunset reviews. In the case of a WTO dispute, the process is more legalistic, and this process may also be quite lengthy. For example, in April 1998 Poland filed a WTO dispute alleging that Thailand improperly imposed antidumping duties on their imports of steel shapes. A WTO panel circulated a report finding in favor of Poland in September 2000, but the two countries did not reach a mutually satisfactory agreement until January 2002.

In contrast, retaliatory AD actions can occur quite quickly. Consider two examples (perhaps not typical). In August 2001, several Indian firms including Reliance Industries filed an $\mathrm{AD}$ petition against Turkish firms exporting "partially oriented yarn" (a synthetic fiber) - the final AD duties were substantial varying by firm between 49 and 139 percent. One of these Turkish firms, Sasa Dupont Sabanci Polyester (along with another firm), then filed an AD petition in April 2002 against several Indian firms (including Reliance Industries) exporting “polyester synthetic staple fibers", ultimately resulting in $\mathrm{AD}$ duties of up to 24 percent.

Another such case involved Canada and India. Canadian firms filed an AD petition in March 2001 against several Indian exporters of hot-rolled carbon steel sheet resulting in duties of $34 \%$. One of these firms, Jindal, then filed an AD petition in August 2001 against Canadian exporters of cold-rolled flat products (though not the firms who had brought the original Canadian AD case). 
That being said, the DSU process can be much quicker if the two countries reach a settlement prior to the formation of the panel- this settlement can take the form of the foreign country removing the antidumping protection. In both cases, the domestic country will be more successful in pressuring the foreign government to remove the antidumping action if they have greater retaliation capacity_-particularly if they account for a greater share of the foreign government's total exports. Should the retaliatory action successfully result in the removal of AD protection, the benefits of such removal will be greater the greater the value of trade associated with the protection.

Note that removal of the antidumping protection may not be the only motivation associated with retaliatory action. For example, consider the theoretical model first espoused in Blonigen and Bown (2003) in which two countries play an infinitely repeated game that includes the choice of output and whether to file for antidumping protection. In this model, retaliatory antidumping cases may be the result of a trigger strategy in which the domestic economy chooses to punish the foreign country for its initial antidumping action. The goal of such punishment may be to deter future antidumping actions rather than force the removal of the current $\mathrm{AD}$ duties. Once could imagine countries choosing the filing of a WTO dispute as a substitute punishment in a similar trigger strategy. The benefits of such a trigger strategy will be greater the more bilateral trade between the two countries more generally. 
One unique benefit of filing a successful WTO dispute, particularly those that result in a formal panel finding, is that WTO panels set precedents and can force changes in the foreign countries antidumping regulations that may lessen the likelihood of future antidumping actions. For example, numerous WTO disputes files since 1995 targeted US use of a practice known as "zeroing," which the United States eventually agreed to stop using in their calculation of antidumping duties in 2012.

\section{Data and Econometric Methodology}

Using data from the World Bank’s Temporary Trade Barriers Antidumping Database we create a dataset of the 4,020 antidumping petitions filed by 47 individual countries between 1995 and 2011; over two-thirds of these petitions resulted in the imposition of antidumping duties. ${ }^{7}$ The number of antidumping instigators clearly reflects the proliferation of antidumping protections that has been well documented in the literature in such papers as Zanardi (2004). However, it should be noted that three entities -- India, the United States, and the European Union -- account for over one-third of these petitions, and the top 10 users of antidumping protection account for three quarters of all petitions filed between 1995 and 2011.

We consider two potential responses that the targets of these antidumping petitions could have. First, using the data from the World Bank and WTO on DSU cases related to specific $\mathrm{AD}$ cases, we construct a dummy variable for those petitions which are

\footnotetext{
${ }^{7}$ Bown, Chad P. (2015) "Global Antidumping Database," The World Bank, June, available at http://econ.worldbank.org/ttbd/gad/
} 
the subject of a WTO dispute within 3 years of the initial petition. ${ }^{8}$ Note that in creating this dummy variable, we exclude those WTO disputes associated with antidumping procedures that are not tied to specific antidumping petitions. We also exclude those disputes launched against antidumping actions more than three years from the initiation of the antidumping investigation, as these petitions are more likely in response to reviews of those antidumping actions rather than the initial imposition of antidumping protection. ${ }^{9}$

Second, we use the Temporary Trade Barriers database referenced above to create a dummy variable that equals 1 if the target of the antidumping petition filed a retaliatory antidumping petition within one year of the initiation of the initial antidumping investigation. ${ }^{10,11}$ Of course, we recognize that firms, not governments, file AD cases, but - especially in the developing world - this may not always be a meaningful distinction. ${ }^{12}$ However, to better capture this distinction we postulate that those antidumping petitions filed in the same sector may be more likely to be retaliatory than those filed in other sectors, and we run each specification with our retaliation variable

\footnotetext{
${ }^{8}$ Bown, Chad P. (2015) "WTO Dispute Database," The World Bank, June, available at http://econ.worldbank.org/ttbd/dsud/ .

${ }^{9}$ Although three years is admittedly a somewhat arbitrary time period, 67 percent of all antidumpingrelated WTO disputes are filed within three years of the initiation of the antidumping investigation; the median time between the initiation of the antidumping investigation and the WTO dispute associated with that investigation is two years.

${ }^{10}$ We specifically choose to study the potential retaliatory response to the initiation of the investigation and not just the response to the imposition of antidumping duties. Previous research, including Prusa (1992), has found that withdrawn antidumping petitions restrict trade by as much, if not more, as those that result in antidumping duties. Nevertheless, in our empirical work we also study to what degree successful antidumping petitions - those that result in antidumping duties - are more likely to result in a retaliatory action.

${ }^{11}$ While we refer to this as a 1-year effect, we actually code any antidumping investigation launched by the target against the original instigator of the antidumping action as retaliatory if it occurred between 60 days and 425 days of the initiation of the original antidumping investigation. We postulate that those petitions filed fewer than 60 days from the initial initiation were likely already in the pipeline and thus are unlikely to be retaliatory.

${ }^{12}$ Hartigan and Vandenbussche (2013) make this point, in particular noting incentives and policy changes that governments can use to encourage antidumping petitions.
} 
both narrowly defined as a same-sector antidumping petition and more broadly as any antidumping petition filed within the year. Sectors, in this case, are defined as one of 99 two-digit Harmonized System (HS) chapters.

Of the more than 4,000 antidumping petitions in our initial sample, about 3 percent result in a subsequent WTO dispute. A similar number (also 3 percent) result in what we define as a retaliatory antidumping action within one year in the same sector. This percentage increases significantly, to 27 percent, if we more broadly define retaliatory action as any antidumping petitions filed against the instigator by the target within one year. Slightly over 1 percent of petitions resulted in both a WTO dispute and a retaliatory action, suggesting that some countries may pursue complementary strategies.

As illustrated in Figure 1, there has been some fluctuation in the percentage of antidumping petitions resulting in retaliatory action. For example, in both 2009 and 2011 over 6 percent of petitions resulted in a subsequent WTO dispute. Apparent sectorspecific retaliatory antidumping petitions peaked in 2003. Figure 2 explores whether there may be heterogeneity across countries in the response to antidumping actions, specifically looking at the top 10 targets of antidumping actions between 1995 and 2011. As can be seen, some countries, including the United States, China and India, are much more likely to file a retaliatory antidumping action in the same sector, while Japan filed no sector-specific retaliatory antidumping actions. Similarly, India and Brazil were much more likely to file WTO disputes in response to antidumping actions taken against their industries when compared to other countries. 
To attempt to explain these patterns, we run a series of regressions explaining what determines a country's decision to retaliate against a particular antidumping action. First we combine two potential responses, (1) a retaliatory antidumping action or (2) a petition with the WTO's disputes settlement body, into a single retaliatory response and estimate a probit regression to explain a country's choice of any form of retaliation. Next, we study these as two separate decisions and estimate separate probit regressions to explain a country's decision to retaliate through either an antidumping action or the WTO. We then focus solely on those countries that have chosen to retaliate in one of these two ways to study what determines whether a country will pursue a more legalistic response, a WTO dispute, rather than a retaliatory antidumping action. Finally, we estimate a bivariate probit to explain a country's simultaneous choice of whether (1) to file a retaliatory antidumping action and (2) to file a WTO dispute in response to an antidumping action against one of its industries. The bivariate probit will allow us to explore more fully whether countries consider WTO disputes complementary or a substitute for retaliatory antidumping action.

To explain these choices, we consider a number of possible explanatory variables motivated by the cost/benefit model outlined above. For example, the benefits of pursuing either retaliatory action against the initial instigator of the antidumping action will be higher if such retaliation leads to an eventual repeal of the antidumping action. As a result, we expect the likelihood of both forms of retaliatory action to be greater when the antidumping investigation resulted in the imposition of antidumping duties 
(Affirmative AD Outcome) and the greater the value of the country's exports at risk from these antidumping duties (Instigator's Sectoral Imports from Target). The target country may be more successful in pressuring for the repeal of the antidumping duty the greater their retaliatory capacity (Retaliation Capacity), which we measure as the share of the Instigator's exports imported by the target country. ${ }^{13}$

A number of factors may influence the cost of pursuing these retaliatory actions. For example, countries with extensive experience with antidumping petitions may find it relatively inexpensive to file a retaliatory antidumping action. To capture this, we include a variable that measures the antidumping experience of the target country (Antidumping Usage, Target), as measured by the average annual number of antidumping petitions filed by the target country between 1995 and the year of the petition under consideration for retaliation. Target countries that are not members of the WTO can clearly not use the WTO's dispute settlement system to complain about an antidumping action (WTO Member, Target).

Less developed target countries may have less legal capacity, which may make it more challenging for them to pursue either a WTO dispute or an antidumping action. On the other hand, targets may be able to extract more concessions by pursuing a retaliatory strategy against a developing country which has fewer resources to counteract this

\footnotetext{
${ }^{13}$ All trade values were downloaded from the United Nation's Commodity Trade Database (COMTRADE). Trade values are converted to 2010 dollars using the International Monetary Fund's Import Price Index.
} 
retaliation. To control for both possibilities we include the GDP per capita of the both the target and instigator. ${ }^{14}$

The target country may feel it more important to retaliate against a country in which it has a significant trading relationship, particularly if the goal of the retaliatory action is to prevent future antidumping actions on an important source of export income, as in the Blonigen and Bown (2003) model. On the other hand, target countries may be wary of taking actions against important trading partners in fear of prompting a lengthy trade wars. We include a variable, Importance of Trade Relationship (Target), which is measured as the target country's total trade with the instigator (exports + imports) as a share of its total GDP, although we are agnostic as to what impact it should have on the target country's decision to retaliate.

Finally, to capture potential macroeconomic determinants of antidumping petitions that may or may not be related to retaliatory action, we include the annual GDP growth of the target country in the year of the initial antidumping action (Annual GDP Growth, Target). In other specifications, we also interact this variable with sectorspecific dummies to control for potential heterogeneity in industry behavior in response to macroeconomic fluctuations. ${ }^{15}$

\footnotetext{
${ }^{14}$ GDP and GDP per Capita data were collected from the World Bank's World Development Indicators database.

${ }^{15}$ Specifically, we interact the targeted country's GDP growth with dummies for the HS Section of the antidumping petition. In other specifications not reported in this paper we include year dummy variables to absorb macroeconomic forces; results from our key parameters of interest are qualitatively the same.
} 
Summary statistics associated with both the dependent and explanatory variables in our model are included in Table 1. Note that our final sample is 3,599 petitions, significantly less than the 4,020 petitions filed between 1995 and 2011. We are forced to eliminate from the sample all petitions filed against Taiwan (267 petitions), North Korea (3 petitions), Faroes Islands ( 2 petitions), Iraq (1 petition), Iran (21 petitions), and Liechtenstein (1 petition), due to challenges finding accurate trade and other economic data for these countries. We also drop an additional 135 petitions that appear to be duplicate observations. In other words, instigators filed a number of petitions against the same target country and in the same sector on the same day—petitions that are likely highly correlated with one another and result in identical retaliatory responses.

\section{Results}

Table 2 displays the marginal effects associated with a probit regression explaining the target country's decision to retaliate through either (1) a retaliatory antidumping action within one year of the initiation of the antidumping investigation or (2) a WTO dispute within three years of the initiation. While the definition of a retaliatory antidumping action is limited in columns 1 and 2 to include only those cases filed within the same HS chapter as the initial AD action, columns 3 and 4 expand the concept of retaliation to include any antidumping action filed by the target against the initial instigator within 1 year of the initial antidumping dispute.

Most of our coefficient estimates are of the expected sign and statistically significant. Thus, for example, we find that the target is more likely to engage in 
retaliatory action when the initial antidumping petition resulted in protection, and when this protection was imposed in a sector involving a larger value of the target country's exports. Note that the predicted probability that a given AD action will result in a (sectoral level) retaliatory action is 6.0 percent. Column 1 suggests that affirmative antidumping investigations are 4.2 percentage points more likely to result in retaliatory actions compared to others. ${ }^{16}$ For every 10 percent increase in the value of sectoral exports related to the $\mathrm{AD}$ action, the likelihood of engaging in a retaliatory action increases by a small but statistically significant 0.12 percentage points. Put another way, a 1 standard deviation increase in this variable would increase the likelihood of engaging in retaliatory action by 2.7 percentage points.

The target country's familiarity with these institutions also plays an important role in the decision of whether to take a retaliatory action. For example, for every 1 petition increase in the average annual antidumping usage of the target country, the likelihood of taking retaliatory action increases by 0.2 percentage points - a 1 standard deviation increase in this variable would increase the likelihood of retaliation by 2 percentage points. WTO Members (who alone have the option of filing a WTO dispute) are not significantly more likely to take retaliatory action when we use a narrow definition of retaliation based on the two-digit HS chapter, but there is evidence that these countries are significantly more likely to take retaliatory action when we broaden our definition of retaliation as in Columns 3 and 4, by as much 12 percentage points.

\footnotetext{
${ }^{16}$ While not a trivial impact, this is consistent with some retaliatory motive even if the antidumping case fails to lead to a final affirmative outcome (consistent with Prusa (1992)).
} 
There is fairly strong evidence that countries are more likely to retaliate the greater the importance of the trade relationship to the target, as measured by trade with the instigator country as a share of the target's total GDP; a one standard deviation in this measure leads to a 0.4 to 0.7 percentage point increase in the likelihood of retaliation.

Finally, consistent with previous studies, target countries are more likely to engage in retaliatory action in the face of recessions. Although the average impact of GDP growth reported in Column 1 is insignificant, when we interact this business cycle effect with sector-specific dummies, the joint impact of these coefficients is statistically significant. Moreover, when we expand our definition of retaliation in Column 3, the average impact of GDP growth suggests that for every 1 percentage point decline in GDP growth the likelihood of engaging in retaliatory action increases by 0.5 percentage points.

In general, results are similar whether we define retaliation narrowly as samesector $\mathrm{AD}$ actions, or more broadly in Columns 3 and 4 . The magnitudes of many of the marginal effects are larger than Columns 3 and 4, but they are based on a much higher average probability of retaliation of nearly 25 percent in Columns 3 and 4 compared to only 6 percent in Columns 1 and 2 .

Table 3 displays the marginal effects associated with three separate probit regressions. Column 1 includes the determinants of filing a sectoral (same HS chapter) level retaliatory antidumping petition, Column 2 includes the determinants of filing any retaliatory $\mathrm{AD}$ petition, and Column 3 includes the determinants of pursuing a dispute 
settlement case at the WTO. Most of the results in Columns 1 and 2 mirror those from the earlier specifications which combines the antidumping and DSU decision into a single retaliation decision. This is likely due to the fact that filing a retaliatory dumping case is much more likely in our sample than filing a dispute settlement case, thus the marginal effects in Table 2 are primarily identified by the determinants of the decision to file an antidumping petition. Closer examination of Table 3 reveals some noticeable differences. For example, countries are less likely to file sectoral-level retaliatory antidumping cases against developing countries, but the level of development of the instigator does not appear to influence the likelihood of filing a retaliatory WTO dispute. Countries are more likely to file a retaliatory antidumping petition against countries with which they have a larger trade relationship, but again this characteristic does not appear to impact the likelihood of filing a WTO dispute

To explore this question further, we next explore what determines whether they will choose to pursue the more legalistic approach offered by the WTO's dispute settlement body, given that the target country has chosen to respond through some retaliatory action. Table 4 presents the marginal effects from a probit regression estimating the determinants of the target country filing a WTO dispute conditional on engaging in any retaliatory action. Note that the sample in Columns 1 and 2, in which the sample is restricted to same-sector retaliation or dispute, is much smaller than that when we define retaliation much broader as any $\mathrm{AD}$ action against the instigator over the next year (in Columns 3 and 4). Note also that we drop the WTO member variable, as only WTO members have the option of pursuing a WTO dispute. 
Consider our preferred specification in Column 2, which limits the definition of retaliation to those within the same chapter and includes sector-specific business cycle effects. Note that the expected probability of choosing to file a WTO dispute settlement case in this sample is 44.8 percent. Not surprisingly, countries are significantly more likely to file a WTO dispute for those cases that resulted in affirmative AD determinations - countries are 42.2 percentage points more likely to respond via the WTO dispute settlement system for affirmative AD petitions. However, countries are less likely to choose a WTO dispute as the size of trade in the sector targeted by the antidumping petition increases. For each 1 percent increase in the real value of trade related to the antidumping petition (as measured by the instigator's sectoral imports from the target), the likelihood of choosing a WTO dispute settlement as a form of response decreases by 0.05 percentage points. Put another way, a one standard deviation increase in the value of sectoral trade associated with the antidumping petition reduces the odds of responding through a WTO dispute by 12.1 percentage points. Countries may choose to respond through an antidumping case when the stakes are higher because they are more likely to get an immediate response.

Targets are less likely to respond via the formal WTO system when their trade relationship with the instigating country is more important, perhaps because they are more likely to secure a change in the instigator's behavior (and/or a repeal of the antidumping order) through the less formal retaliation channel. For every 1 percentage 
point increase in the importance of trade with the instigator as a share of GDP, the likelihood of pursing a WTO dispute decreases by 2.7 percentage points.

We find that countries are more likely to choose to respond to $\mathrm{AD}$ petitions through the WTO dispute settlement system when the instigator is more developed-our estimates suggest that a 1 percent increase in the GDP per capita of the instigator increases the likelihood of filing a WTO dispute by 0.1 percentage points. Alternatively, a 1 standard deviation increase in the GDP per capita of the instigating country increases the likelihood of pursuing a WTO dispute by 15.3 percentage points.

Our final approach estimates a bivariate probit regression, jointly estimating the determinants of (1) filing a retaliatory antidumping duty and (2) filing a WTO dispute, the results of which are reported in Table 5. Estimating each of these equations separately, as in Table 3, could lead to biased results if there is an overlap in the unobserved characteristics that determine both the likelihood of pursuing retaliatory antidumping actions and a WTO dispute settlement case. The bivariate probit also allows us to better explore the relationship between retaliatory antidumping petitions and WTO disputes. As above, the first two columns estimate the model with the limited definition of sectoral level $\mathrm{AD}$ retaliation, and the final two columns expand the definition to any antidumping case filed within one year.

First, we see that there is a significant negative correlation in the errors associated with the joint decision to file sectoral level AD retaliation and a WTO dispute, at least 
when we use the broader definition of retaliation in columns 3 and 4 . These results indicate that there is likely some unobserved factor(s) that impact both the decision to file a retaliatory antidumping petition and WTO dispute, but while it positively impacts one decision it has a negative impact on the other decision.

Perhaps more interestingly, we find a statistically significant, positive impact of the decision to file a retaliatory antidumping petition on the decision to file a WTO dispute, suggesting that these two retaliatory strategies may be complementary. Our coefficient estimates indicate that filing a retaliatory, sectoral-level antidumping petition increases the marginal probability of filing a WTO dispute by 2.0 percentage points. When we expand our definition of retaliatory AD petitions to include any antidumping petition over the year following the initial action, the impact on this marginal probability of filing a dispute is 4.3 percentage points. This is a meaningful increase, given the average marginal probability of filing a WTO dispute is 1.1 percent in the first model and 1.2 percent in the latter.

Other results generally mirror those we have found in earlier specifications. Countries are more likely to pursue retaliatory strategies when the antidumping investigation in question resulted in an affirmative determination and imposition of antidumping duties. Retaliatory strategies also become more likely as the value of trade associated with the antidumping investigation increases. 
The likelihood of filing a retaliatory antidumping petition increases with the target country's familiarity with antidumping regulations. For example, our parameter estimates suggest the likelihood of filing a retaliatory sectoral level antidumping case instead of a WTO dispute increases by 0.05 percentage points for every 1 petition increase in the average annual number of antidumping petitions filed by the target country. A one standard deviation in this variable essentially results in a 0.5 percentage point increase in the likelihood of pursuing a retaliatory antidumping action but not a WTO dispute (from an average probability of just 0.4 percent). ${ }^{17}$

As we found in Table 2, there does not seem to be a significant effect of retaliation capacity on the decision to retaliate (either via a DSU filing or an AD case) but there is evidence that countries are more likely to file a retaliatory antidumping petition against countries that are more important trade partners (as shown earlier in Table 3).

\section{Conclusion}

Participation in the WTO dispute resolution process has been increasing and we contribute in this paper to an understanding of the determinants of this growth. While others have examined determinants of DSU petitions, we consider this activity as a more general part of the process of responding to antidumping actions. Those targeted by $\mathrm{AD}$

\footnotetext{
${ }^{17}$ Because we are using a bivariate probit model, there are a number of potential outcomes that we can estimate the marginal effect of an explanatory variable upon, including the likelihood that a country (1) files both a WTO dispute and a retaliatory AD petition; (2) files a WTO dispute but not a retaliatory petition; (3) files a retaliatory petition but not a WTO dispute; and (4) does not pursue either retaliation strategy.
} 
have several options for response and here we have examined the choices made between inaction and retaliating via a new AD petition or going directly to the WTO via a DSU action (or both).

Based on several econometric models applied to close to 4000 antidumping cases filed since 1995, we find evidence supporting previous work noting macroeconomic determinants of case-filing behavior. It seems that countries are less likely to file a retaliatory antidumping response against wealthier instigator countries, but given some response a WTO DSU case is more likely the wealthier the instigator country is.

Not surprisingly, larger sectoral export flows from the target to the instigator country make a retaliatory response more likely, but this response is more likely to be via an antidumping case rather than a DSU case. There is also some suggestion that an important bilateral trade relationship makes the target more likely to focus on a retaliatory AD action instead of the WTO mechanisms for response.

While our results are still somewhat preliminary they do sketch out the ways in which targets of $\mathrm{AD}$ proceedings weigh their options in deciding on a response. To the extent retaliatory AD and DSU petitions are complementary - as suggested here - the DSU mechanism may not be limiting the global use of antidumping. It would be useful in future work to investigate this issue further. 


\section{References}

Blonigen, Bruce A. and Chad P. Bown. 2003. Antidumping and Retaliation Threats. Journal of International Economics 60: 249-73.

Bown, Chad P., "Antidumping Against the Backdrop of Disputes in the GATT/WTO System," working paper June 2002

(http://people.brandeis.edu/ cbown/papers/ad_theory.pdf)

Bown, Chad P., "Participation in WTO Dispute Settlement: Complainants, Interested Parties and Free Riders," World Bank Economic Review, Vol. 19, No. 2, 2005a, pp. 287310.

Bown, Chad P., "Trade Remedies and World Trade Organization Dispute Settlement: Why Are So Few Challenged?” Journal of Legal Studies, Vol. 34, No. 2, 2005b, pp. 515555.

Bown, Chad P., "Trade Policy Flexibilities and Turkey: Tariffs, Anti-Dumping, Safeguards and WTO Dispute Settlement," The World Economy, Vol. 37, No. 2, February 2014, pp. 193-218.

Bown, Chad P. and Kara Reynolds, "Trade Flows and Trade Disputes," Review of International Organizations, 2015, 10(2): 145-177.

Bown, Chad P., and Kara M. Reynolds, "Trade agreements and enforcement: evidence from WTO dispute settlement," American Economic Journal: Economic Policy, forthcoming, 2017.

Busch, Marc L., Eric Reinhardt, and Gregory Shaffer, "Does Legal Capacity Matter? Explaining Dispute Initiation and Antidumping actions in the WTO," 2008, ICTSD Project on Dispute Settlement, Series Issue Paper No. 4, International Centre for Trade and Sustainable Development, Geneva, Switzerland.

Davis, C. L. and S. B. Bermeo, "Who Files? Developing Country Participation in WTO Adjudication,” Journal of Politics, Vol. 71, No. 3, 2009, pp. 1033-1049.

Feinberg, Robert M. and Kara M Reynolds, "The spread of antidumping regimes and the role of retaliation in filings" Southern Economic Journal, Vol. 72, No. 4, 2006, pp. 877890.

Francois, Joseph F. and Gunnar Niels. 2004. Political Influence in a New Antidumping Regime: Evidence from Mexico. Timbergen Institute Working Paper No. TI 2004-011/2.

Guzman, A.T. and B.A. Simmons, "Power Plays and Capacity Constraints: The Selection of Defendants in WTO Disputes," Journal of Legal Studies, Vol. 34, No. 2, 2005, pp. 557-598. 
Hartigan, James C. and Hylke Vandenbussche, "Disfavored Nations: Anti-Dumping at the WTO," Review of Development Economics, Vol. 17, No. 1, 2013, pp. 105-116.

Horn, H., P.C. Mavroidis, and H. Nordstrom, "Is the Use of the WTO Dispute Settlement System Biased?" in Mavroidis \& Sykes (Eds.), The WTO and International Trade Law/Dispute Settlement. Cheltenham, UK: Edward Elgar, 2005.

Johns, L. and K. Pelc, "Who Gets to Be in the Room? Manipulating Participation in WTO Disputes," International Organization, Vol. 68, No. 3, Summer 2014, pp. 663-699.

Knetter, Michael M. and Thomas J. Prusa. 2003. Macroeconomic Factors and Antidumping Filings: Evidence from Four Countries. Journal of International Economics 61: 1-17.

Limao, Nuno and Patricia Tovar, "Policy Choice: Theory and Evidence from Commitment via International Trade Agreements," Journal of International Economics, Vol. 85, No. 2, 2011, pp. 186-205.

Miranda, Jorge, Raul A. Torres, and Mario Ruiz. 1998. The International Use of Antidumping: 1987-1997. Journal of World Trade 32: 5-71.

Prusa, Thomas J. 1992. Why are so many antidumping petitions withdrawn? Journal of International Economics 33.1-2: 1-20.

Prusa, Thomas J. 2001. On the Spread and Impact of Antidumping. Canadian Journal of Economics 34: 591-611.

Prusa, Thomas J. and Susan Skeath. 2002. The Economic and Strategic Motives for Antidumping Filings. Weltwirtschaftliches Arhiv 138: 389-413.

Zanardi, Maurizio, "Anti-dumping: What are the Numbers to Discuss at Doha?" The World Economy, 2004. 
Table 1

Summary Statistics

\begin{tabular}{lrrrr}
\hline & Mean & Std. Dev. & Min & Max \\
\hline Dependent Variables & & & & \\
Sectoral-Level AD Retaliation & 0.03 & 0.18 & 0.00 & 1.00 \\
Any AD Retaliation & 0.27 & 0.44 & 0.00 & 1.00 \\
WTO Dispute & 0.03 & 0.17 & 0.00 & 1.00 \\
& & & & \\
Explanatory Variables & & & & \\
Ln(Instigator's Sectoral Imports & & & & \\
$\quad$ from Target) & 4.75 & 2.25 & 0.00 & 12.18 \\
Affirmative AD Outcome & 0.68 & 0.47 & 0.00 & 1.00 \\
Antidumping Usage, Target & 8.02 & 10.47 & 0.00 & 41.00 \\
WTO Member, Target & 0.85 & 0.35 & 0.00 & 1.00 \\
Importance of Trade Relationship, & & & & \\
$\quad$ Target & 0.04 & 0.07 & 0.00 & 0.96 \\
Retaliation Capacity & 0.05 & 0.10 & 0.00 & 0.81 \\
Ln(GDP per Capita), AD Instigator & 8.76 & 1.47 & 6.15 & 10.72 \\
Ln(GDP per Capita), Target & 8.69 & 1.38 & 5.42 & 11.27 \\
Annual GDP Growth, Target & 0.05 & 0.04 & -0.16 & 0.20 \\
$\quad$ Number of Obs. & 3,599 & & & \\
\hline
\end{tabular}

Table Notes: The AD Instigator is the country filing the initial antidumping petition against the target country. Antidumping usage is the average annual number of antidumping petitions filed by the target country between 1995 and the year of the petition. The importance of the trade relationship to the target country is total bilateral trade between the AD instigator and target divided by the target country's GDP. Retaliation capacity is defined as the share of the $\mathrm{AD}$ instigator's total exports imported by the target country. 
Table 2

Determinants of Any Retaliation (Marginal Effects)

Sectoral Retaliation

Any Retaliation

(1)

(2)

(3)

(4)

Ln(Instigator's Sectoral

$0.012 * * *$

$0.011 * * *$

$0.045 * * *$

$0.049 * * *$

Imports from Target)

(0.002)

(0.002)

$(0.004)$

$(0.004)$

Affirmative AD

$0.042 * * *$

$0.035 * * *$

$0.033 * *$

$0.029 *$

Outcome

Antidumping Usage,

(0.007)

(0.007)

(0.017)

(0.017)

Target

$0.002 * * *$

$0.002 * * *$

$0.009 * * *$

$0.009 * * *$

WTO Member, Target

(0.000)

(0.000)

(0.001)

(0.001)

0.013

0.014

$0.118 * * *$

$0.124 * * *$

Importance of Trade

(0.011)

(0.010)

(0.028)

(0.028)

Relationship, Target

$0.100 * *$

$0.068 *$

$0.242 * *$

0.189

Retaliation Capacity

(0.041)

(0.038)

(0.118)

(0.119)

$-0.019$

$-0.025$

0.084

0.052

(0.027)

(0.024)

$(0.088)$

(0.089)

Ln(GDP per Capita),

$-0.002$

0.000

$-0.000$

0.003

AD Instigator

(0.002)

(0.002)

(0.006)

(0.006)

Ln(GDP per Capita),

Target

$-0.003$

$-0.002$

0.003

0.002

(0.003)

(0.002)

(0.007)

$-0.098$

$-0.501 * *$

(0.007)

Annual GDP Growth,

(0.083)

(0.214)

Sectoral Business Cycle Effects

Yes

Yes

Chi-Squared Test

54.55

49.03

Observations

3,599

3,599

3,599

Pseudo R-squared

0.164

0.204

3,599

0.147

Table Notes: Marginal Effects from a probit regression in which the dependent variable is defined as 1 if the target country (1) filed an AD petition within 1 year of the AD action or (2) filed a WTO Dispute within three years of the AD action. Standard errors in parentheses. $* * * p<0.01, * * p<0.05, * p<0.1$. ChiSquared Test is the test of the joint significance of the interaction between the section of the antidumping petition and the annual GDP growth in the target country. 
Table 3

Determinants of Specific Forms of Retaliation (Marginal Effects)

\begin{tabular}{lccc}
\hline & $(1)$ & $(2)$ & $(3)$ \\
VARIABLES & Sectoral AD & Any AD & DSU \\
\hline Ln(Instigator's Sectoral & $0.004^{* * *}$ & $0.047^{* * *}$ & $0.005^{* * *}$ \\
Imports from Target) & $(0.001)$ & $(0.004)$ & $(0.001)$ \\
Affirmative AD & $0.004^{*}$ & 0.019 & $0.027^{* * *}$ \\
$\quad$ Outcome & $(0.002)$ & $(0.016)$ & $(0.005)$ \\
Antidumping Usage, & $0.001^{* * *}$ & $0.009^{* * *}$ & \\
Target & $(0.000)$ & $(0.001)$ & \\
WTO Member, Target & $-0.005^{*}$ & $0.105^{* * *}$ & \\
& $(0.003)$ & $(0.028)$ & \\
Importance of Trade & $0.030^{* *}$ & 0.189 & 0.010 \\
Relationship, Target & $(0.013)$ & $(0.117)$ & $(0.026)$ \\
Retaliation Capacity & -0.008 & 0.068 & 0.017 \\
& $(0.008)$ & $(0.086)$ & $(0.014)$ \\
Ln(GDP per Capita), & $-0.001^{* *}$ & 0.002 & 0.001 \\
AD Instigator & $(0.001)$ & $(0.006)$ & $(0.001)$ \\
Ln(GDP per Capita), & $-0.002^{* *}$ & 0.005 & $0.003^{*}$ \\
Target & $(0.001)$ & $(0.007)$ & $(0.002)$ \\
& & & \\
Sectoral Business Cycle Effects & Yes & Yes & Yes \\
Chi-Squared Test & 58.14 & 45.53 & 33.82 \\
Observations & 3,599 & 3,599 & 3,599 \\
Pseudo R & 0.313 & 0.146 & 0.140 \\
\hline
\end{tabular}

Table Notes: Marginal Effects from a probit regression in which the dependent variable is defined as 1 if the target country $(1,2)$ filed an AD petition within 1 year of the AD action or $(3)$ filed a WTO Dispute within three years of the AD action. Standard errors in parentheses. $* * * p<0.01, * * \mathrm{p}<0.05, * \mathrm{p}<0.1$. ChiSquared Test is the test of the joint significance of the interaction between the section of the antidumping petition and the annual GDP growth in the target country. 
Table 4

Determinants of WTO Dispute (Marginal Effects)

\begin{tabular}{|c|c|c|c|c|}
\hline \multirow[t]{2}{*}{ Sample } & \multicolumn{2}{|c|}{ Sectoral Level Retaliation } & \multicolumn{2}{|c|}{ Any Retaliation } \\
\hline & $(1)$ & $(2)$ & $(3)$ & (4) \\
\hline \multirow{2}{*}{$\begin{array}{l}\text { Ln(Instigator's Sectoral } \\
\text { Imports from Target) }\end{array}$} & $-0.068 * * *$ & $-0.054^{*}$ & 0.002 & 0.007 \\
\hline & $(0.025)$ & $(0.032)$ & $(0.005)$ & $(0.005)$ \\
\hline \multirow{2}{*}{$\begin{array}{l}\text { Affirmative AD } \\
\text { Outcome }\end{array}$} & $0.357 * * *$ & $0.422 * * *$ & $0.140 * * *$ & $0.119 * * *$ \\
\hline & $(0.118)$ & $(0.138)$ & $(0.023)$ & $(0.025)$ \\
\hline \multirow{2}{*}{$\begin{array}{l}\text { Antidumping Usage, } \\
\text { Target }\end{array}$} & $-0.010 * *$ & $-0.013 * * *$ & 0.000 & 0.000 \\
\hline & $(0.004)$ & $(0.005)$ & $(0.001)$ & $(0.001)$ \\
\hline \multirow{2}{*}{$\begin{array}{l}\text { Importance of Trade } \\
\text { Relationship. Target }\end{array}$} & -0.989 & $-2.667 * *$ & 0.202 & 0.042 \\
\hline & $(0.888)$ & $(1.206)$ & $(0.165)$ & $(0.152)$ \\
\hline \multirow[t]{2}{*}{ Retaliation Capacity } & -0.022 & -0.212 & -0.002 & -0.049 \\
\hline & $(0.369)$ & $(0.526)$ & $(0.071)$ & $(0.066)$ \\
\hline \multirow{2}{*}{$\begin{array}{l}\text { Ln(GDP per Capita), } \\
\text { AD Instigator }\end{array}$} & $0.157 * * *$ & $0.104 * *$ & $0.013^{*}$ & 0.004 \\
\hline & $(0.039)$ & $(0.045)$ & $(0.007)$ & $(0.006)$ \\
\hline \multirow{2}{*}{$\begin{array}{l}\text { Ln(GDP per Capita), } \\
\text { Target }\end{array}$} & $0.149 * * *$ & $0.119 * *$ & 0.010 & 0.010 \\
\hline & $(0.047)$ & $(0.056)$ & $(0.008)$ & $(0.007)$ \\
\hline \multirow{2}{*}{$\begin{array}{l}\text { Annual GDP Growth, } \\
\text { Target }\end{array}$} & -1.907 & & $-0.571 * *$ & \\
\hline & $(1.399)$ & & $(0.288)$ & \\
\hline Sectoral Business Cycle Effects & No & Yes & No & Yes \\
\hline Chi-Squared Test & & 35.19 & & 26.77 \\
\hline Observations & 213 & 213 & 992 & 992 \\
\hline Pseudo R & 0.215 & 0.380 & 0.0726 & 0.125 \\
\hline
\end{tabular}

Table Notes: Marginal Effects from a probit regression in which the dependent variable is defined as 1 if the target country filed a WTO complaint regarding the AD action within three years of the initial petition. Sample is limited to those targeted countries that have chosen to retaliation through either an AD action or a WTO dispute. Standard errors in parentheses. $* * * \mathrm{p}<0.01, * * \mathrm{p}<0.05, * \mathrm{p}<0.1$. Chi-Squared Test is the test of the joint significance of the interaction between the section of the antidumping petition and the annual GDP growth in the target country. 
Table 5

Determinants of Retaliation: Bivariate Probit

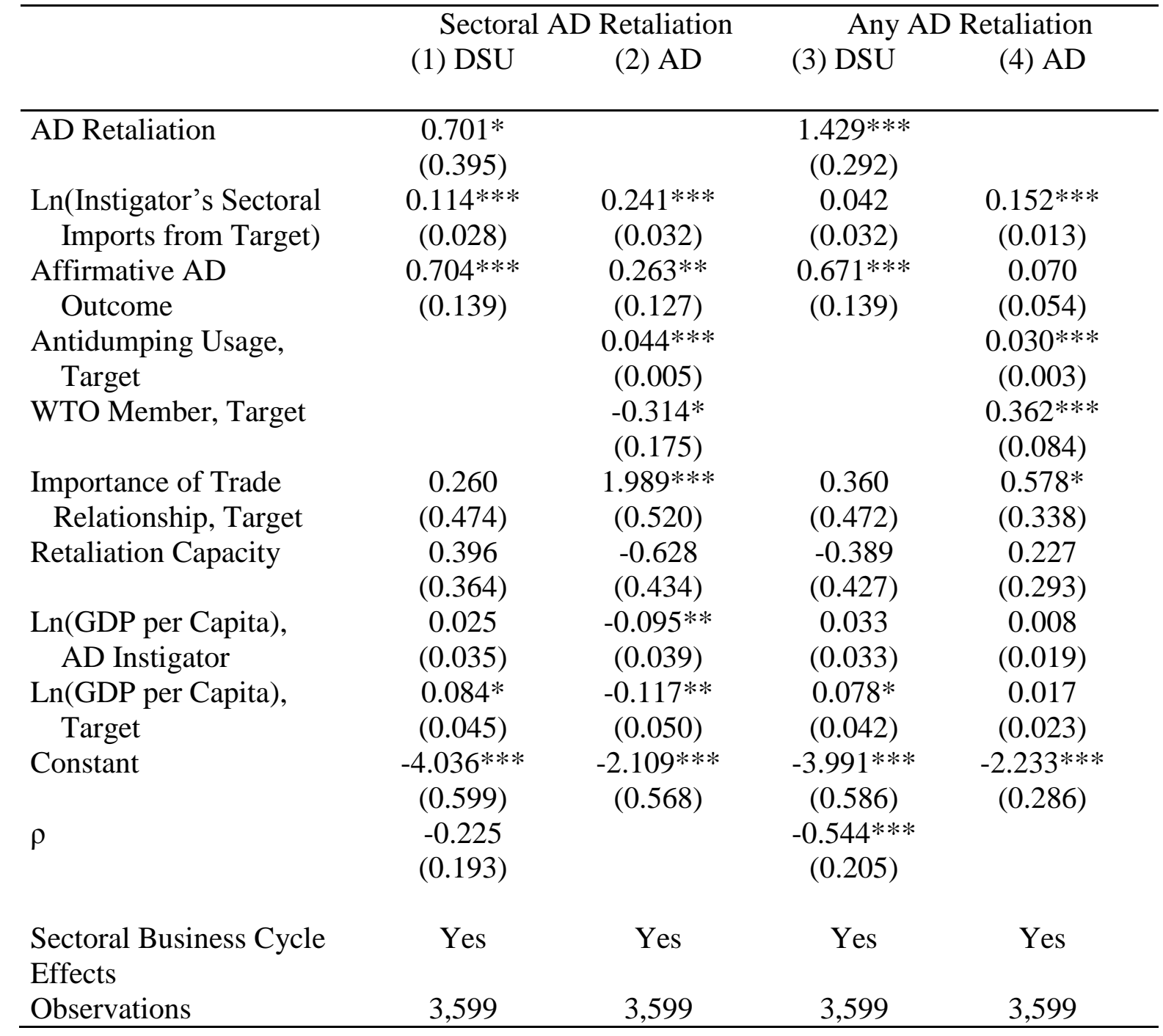

Table Notes: Coefficient estimates from a seemingly unrelated bivariate probit. Standard errors in parentheses. $* * * \mathrm{p}<0.01, * * \mathrm{p}<0.05, * \mathrm{p}<0.1$. 
Figure 1

Antidumping Petitions, 1995-2011

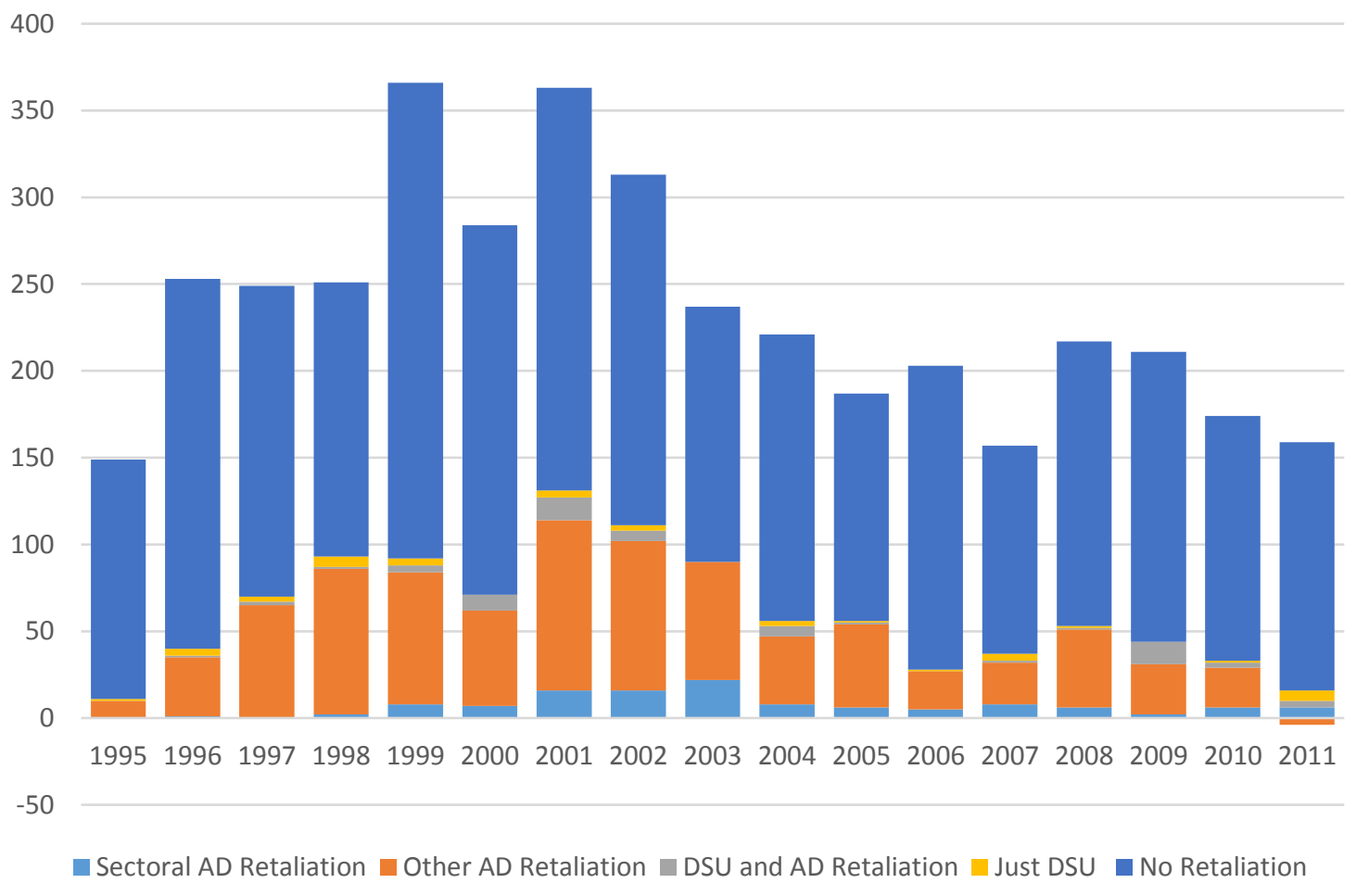


Figure 2

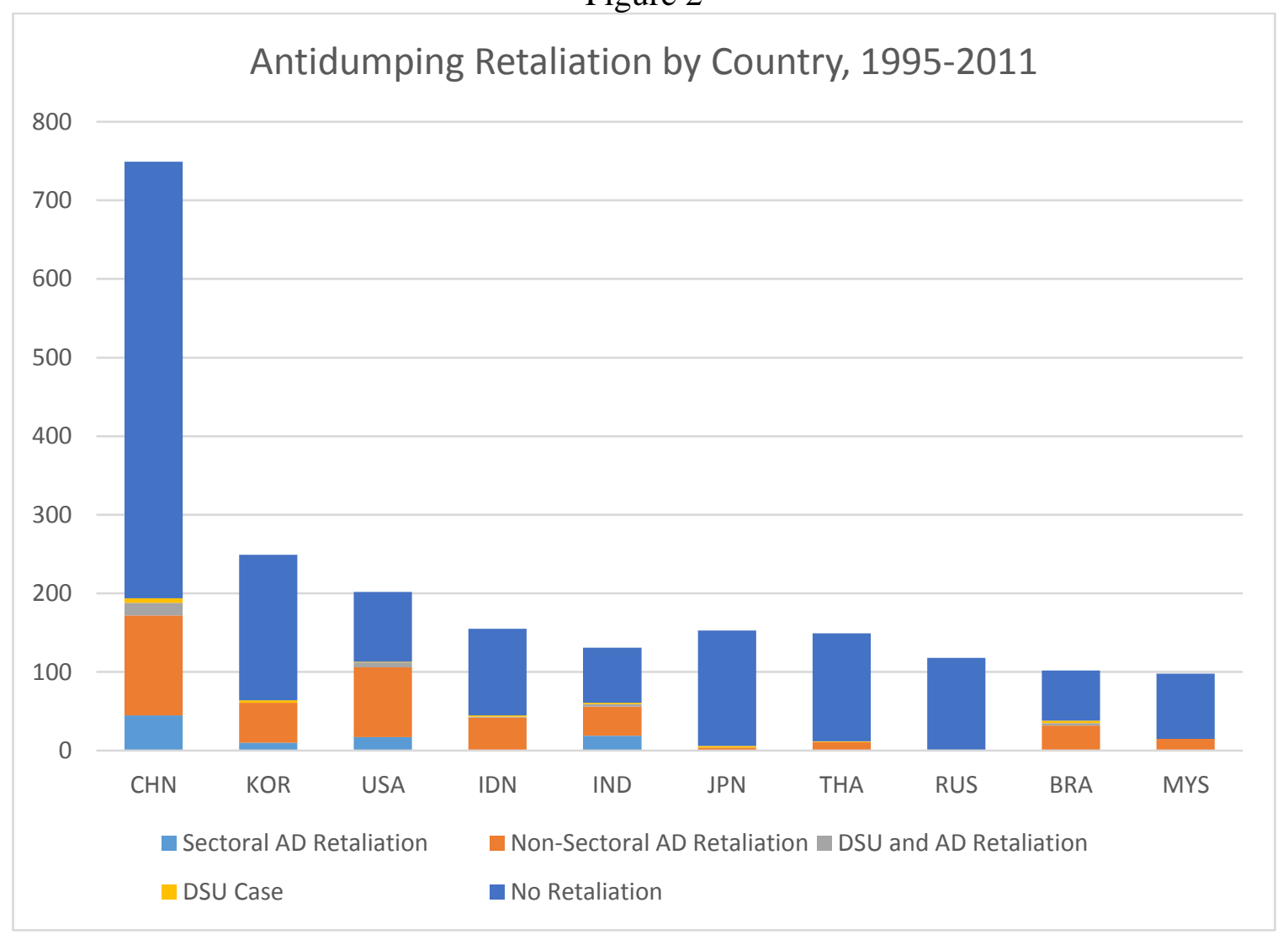

